УДК: $7.032(39)$

ББК: $63.3(0) 32$

DOI: 10.18688/aa2111-01-01

\title{
A. Corso
}

\section{When and Why Ancient Art Became Anonymous}

The visual arts of the Roman period are characterized by prominent artists and architects.

Already in the middle of the $2^{\text {nd }}$ century BC, Hermodoros of Salamis [9, pp. 545-568] creates the standard Roman model of a temple.

In late republican times, Kyros and Diphylos projected Roman villas (Kyros: Cicero, Q. Fr. 2, 2, 2; id. Att. 2, 3, 2 and 4, 10, 2; id. Mil. 17, 46; Diphylos: Cicero, Q. Fr. 3. 1. 1 and Vitruvius 7 praefatio 14 ).

In sculpture, dynasties of masters developed the visual style which will be peculiar of Roman classicism: Pasiteles [18], the Kleomeni [29], Apollonios of Nestor [24], Stephanos, Agesander, Polydoros and Athonodoros [25], etc.

In painting, Timomachos of Byzantium [21] inaugurated Roman classicism in the realm of pictures.

Studius created landscape painting [20].

In the early imperial times, we find the important personalities of Severus and Celer, the architects of the Domus Aurea [12], of Zenodorus, sculptor of Neros' Colossus [2], and of Famulus, painter of the Domus Aurea [23].

In the age of Domitian, Rabirius created the model of the palatine palace [28], one generation later Apollodorus of Damascus projected both Trajan's forum and markets and may have been also the master of Trajan's column [5].

During the Antonine period, we have the important personality of Zenon, the architect of the theatre of Aspendos [6].

Moreover, the period from the $1^{\text {st }}$ century BC to $2^{\text {nd }}$ century AD sees the frequent habit by sculptors, gem cutters, master of mosaics, sometimes painters, to sign their works [16, vols. 4 and 5].

However, from around the time of Septimius Severus onwards, we see a drop in the habit of signing works of art.

Moreover, the most important ekphrastic writer of this period, Flavius Philostratus, describes pictures in an art gallery without giving their authorship [26].

This habit is followed also by a younger writer of the same family - Philostratus the younger - who also does not inform about the painters of the described pictures [13].

Thus, visual arts become anonymous.

Why?

Several reasons determined this outcome.

The first is philosophical. 
Philostratus, in the 'Life of Apollonius of Tyana' 6. 19, claims that works of art, in particular statues of deities, should not respond to the 'mimesis' but to the 'phantasia', that is to the creative imagination inspired by the divine [1].

Thus, the real artist is God, to be interpreted according to Plato's 'Timaeus' as the demiourgos who creates everything.

He is the only perfect artist and thus the real maker of a work of art becomes a translator of the divine, transcendent beauty in the material realm; of course, he can only do bad copies of that absolute beauty and thus he is devaluated.

The second reason is that the number of liberal arts is reduced from 9 to 7 and architecture is excluded from the series of these arts.

This fact, which will become clear in Martianus Capella's De nuptiis Philologiae et Mercurii, expresses a diminution of the status of the architect who is no longer the intellectual who makes the project but the master builder [4].

This conclusion is supported by the observation that even the most important architectural complexes of $\mathrm{AD} 3^{\text {rd }}, 4^{\text {th }}$ and $5^{\text {th }}$ centuries are anonymous: the names of their architects are not recorded.

The personality of the architect disappears because architecture is no longer a liberal art.

The third reason is the transformation of the Roman Empire from a constitutional monarchy which had been set up with the Lex de imperio Vespasiani [7] to an absolute monarchy [17].

Thus, the absolute monarch becomes the only authority to whom the exceptional building is attributed.

Architects, sculptors, painters are no longer allowed to enjoy a slice of the glory of the emperor because the latter becomes a divine, transcendent figure [8]: every enterprise must be attributed to him.

Thus nobody else can take the pride of a monument promoted by him.

So the artist loses much of his previous status.

The fourth reason is the impressive decline in learning which takes place in the age of the military anarchy in the $3^{\text {rd }}$ century $\mathrm{AD}[15]$. The cultural transmission from a generation to the other shrinks.

In the eastern part of the empire, especially after the Herulian and Gothic invasions of the 260s, the ephebia, which provided children with a cultural education, declines [19].

Thus, even the memory of the great past characterized by important artists fades.

Mentions of the great masters of the classical period become rare.

The fifth reason is the cultural life in the age of spirituality.

Late pagans were less interested in style and skills of artists than in the value of statues as epiphanies of deities: they are pilgrims rather than tourists or scholars [11].

The rise of the sense of sanctity of images implies a diminution of the interest for styles of artists.

In $\mathrm{AD} 4^{\text {th }}$ century, we have a restoration of classical culture and several scholars - Himerius, Libanius, Julian etc - are again concerned about classical artists [30].

However, this phenomenon is confined mostly to the eastern and Greek literature: The Latin West is slowly disengaging from the Greek classical heritage.

The sixth reason is the decline of the copyist production. 
Copies from classical masterpieces become rare in the Severan period and sporadic in later times [3].

Of course, this decline contributed to the disappearance of the consideration of sculptures as evidence of styles of artists.

The seventh reason is the widespread pessimism which pervades late ancient societies.

There are intellectuals as Libanius who believe the world in front of them is collapsing and regard their age degenerated [14].

Of course, these pessimistic scholars do not believe that great artists can flourish in their age.

There are also other scholars who believe that contemporary works of art are better than the past ones, for example Ausonius in the 'Mosella' (vv. 298-348).

However, they do not name the artists who made the admired contemporary monuments: they are anonymous, for the above outlined philosophical, religious, political, and cultural reasons.

That is why in the ekphrastic literature of late antiquity, for example of Johannes, Procopius and Choricius of Gaza and of Paul Silentiarius, the artists of the described monuments are not remembered.

This observation applies also to the most important late antique ekphrastic poet in the West: Venantius Fortunatus: he never provides names of architects and artists of the oratoria, palaces, and churches evoked by him.

The case of the Hagia Sophia, whose architects are recorded - Anthemius of Tralles, Isidorus of Miletus and Ignatius - , is an exception.

Thus it is safe to conclude that architects and artists do not enjoy a great acclaim until the cultural change in the West of the late $8^{\text {th }}$ and $9^{\text {th }}$ centuries, when Odo of Metz is recorded as the architect of the Palatine Chapel of Aachen [22] and Einhard mentions again Vitruvius [27, pp.47-50] and in Constantinople until the early $10^{\text {th }}$ century, when a complex of inferiority toward ancient Greece comes to a head, with Aretas of Caesarea and Constantine $7^{\text {th }}$ Porphyrogenitus [10, vol.3].

\section{References}

1. Abbondanza L. Immagini della phantasia. Roemische Mitteilungen, vol. 108, 2001, pp. 111-134 (in Italian).

2. Albertson F. C. Zenodorus's Colossus of Nero. Memoirs of the American Academy at Rome, vol.46, 2001, pp. 95-118.

3. Anguissola A. Remembering with Greek Masterpieces: Observations on Memory and Roman Copies. Galinsky K. (ed.). Memoria Romana: Memory in Rome and Rome in Memory. Ann Arbor, University of Michigan Press Publ., 2014, pp. 117-134.

4. Bovey M. Disciplinae cyclicae: l'organisation du savoir dans l'oeuvre de Martianus Capella. Trieste, Edizioni Università di Trieste Publ., 2003. 406 p. (in French).

5. Calcani G. (ed.). Apollodoro e la colonna traiana. Rome, L'Erma di Bretschneider Publ., 2003. 67 p. (in Italian).

6. Can B. Antoninler dönemi baroğu ışığında Aspendos tiyatrosu bezemeleri. Adalya, vol. 8, 2005, pp. 89119 (in Turkish).

7. Capogrossi Colognesi L.; Tassi Scandone E. La Lex de Imperio Vespasiani e la Roma dei Flavii. Rome, L'Erma di Bretschneider Publ., 2009. 388 p. (in Italian). 
8. Chalupa A. How Did Roman Emperors Become Gods? Various Concepts of Imperial Apotheosis. Anodos, no. 6/7, 2007-2008, pp. 201-207.

9. Coarelli F. Hermodoros di Salamina. Rogge S. (ed.). Salamis of Cyprus. Münster, Waxmann Publ., 2019, pp. 545-568.

10. Corso A. Prassitele. Fonti epigrafiche e letterarie, vol.3. Rome, Leonardo Arte Publ., 1992 (in Italian).

11. Elsner I.; Rutherford I. (eds.). Pilgrimage in Graeco-Roman \& Early Christian Antiquity: Seeing the Gods. Oxford, Oxford University Press Publ., 2005. 513 p.

12. Farinella V. The Domus Aurea. Milan, Electa Publ., 2019. 308 p.

13. Ghedini F. (ed.). Le Immagini di Filostrato Minore. Rome, Edizioni Quasar Publ., 2004. 207 p. (in Italian).

14. Janik J. Libanius and the Death of Julian. Classica Cracoviensia, iss. 21, 2018, pp. 83-94.

15. Johne K.-P. et al. (eds.). Die Zeit der Soldatenkaiser, 2 vols. Berlin, Akademie Verlag Publ., 2008. (in German).

16. Kansteiner S. (ed.). Der Neue Overbeck, 5 vols. Berlin, De Gruyter Publ., 2014. (in German).

17. Kulikowski M. The Triumph of Empire. Cambridge, 2016. 360 p.

18. La Rocca E. Sulla bottega di Pasiteles e di Stephanos. Greco G. (ed.). Kithon Lydios. Naples, Naus Editoria Publ., 2017, pp. 875-895 (in Italian).

19. Laes C.; Vuolanto V. (eds.). Children and Everyday Life in the Roman and Late Antique World. London, Routledge Publ., 2017. 390 p.

20. Ling R. Studius and the Beginnings of Roman Landscape Painting. The Journal of Roman Studies, iss. 67, 1977, pp. 1-16.

21. Lippold G. Timomachos. Paulys Realencyclopädie der classischen Altertumswissenschaft, vol. VI A, 1, 1936 (Thesauros-Timomachos), pp. 1292-1296 (in German).

22. Mann A. Aachens Geschichte und die Geschichten von "Odo von Metz" und dem Karlsthron, von "Aquae Granni" und dem "Grashaus" neben anderen lokalhistorischen Legendenbeiträgen. Aachener Kunstblätter, iss. 61, 1995/97, 1998, pp. 361-369 (in German).

23. Meyboom P.G.P. Famulus and the Painters' Workshops of the Domus Aurea. Mededelingen van het Nederlands Instituut te Rome, iss. 54, 1995, pp. 229-244.

24. Meyer H. Doch Prometheus? Zum Typus des Torso von Belvedere und seiner antiken Wirkungsgeschichte. Boreas, iss. 30/31, 2007-2008, pp. 25-39 (in German).

25. Muth S. (ed.). Laokoon. Rahden, Marie Leidorf Publ., 2017. 502 p.

26. Pucci G. La "Pinacoteca". Palermo, Aesthetica Publ., 2010. 127 p. (in Italian).

27. Schuler W. Vitruv im Mittelalter. Wien Köln Weimar, Böhlau Verlag Publ., 1999. 494 p. (in German).

28. Sojc N. (ed.). Domus Augustana. Leiden, Sidestone Press Publ., 2012. 275 p. (in German).

29. Stewart A. Hellenistic Free-Standing Sculpture from the Athenian Agora 1. Hesperia, iss. 81, 2012, pp. $267-$ 342 .

30. Watts E. J. City and School in Late Antique Athens and Alexandria. Berkeley, University of California Press Publ., 2008. 288 p.

Title. When and Why Ancient Art Became Anonymous

Author. Corso, Antonio - full doctor, research fellow. Kostopoulos Foundation, Livyis 2 a, Zografou, GR 15771, Athens, Greece. antoniocorso@hotmail.com ORCID: 0000-0002-8090-4274

Abstract. In this article, the problem of why ancient art became anonymous in late antiquity is discussed. There are aesthetic reasons: the visual arts are no longer thought to respond to the mimesis but to the 'phantasia', thus the images have a transcendent origin and are no longer attributed to specific artists. Moreover, the passage of the Roman Empire from a constitutional monarchy to an absolutistic one implies that monuments are now attributed especially to the imperial patronage, artists and architects are devaluated. The decline of classical culture, the widespread pessimistic feelings, and finally the disengagement of the western part of the Roman Empire from the classical Greek heritage complete this picture. However, ancient artists will become again renowned from the $9^{\text {th }}$ and $10^{\text {th }}$ century onwards. The artists are mentioned and regarded important until Severan times. From this period onwards, the mentioning of artists becomes rare and disappears. This process is due to a radical change in the aesthetic theory (the phantasia becomes more important that the mimesis), to the transformation of the Roman Empire into an absolutistic monarchy, to the decline in classical education, finally to the establishment of a culture which sees works of art as the epiphanies of deities rather than the creations of artists.

Keywords: phantasia, Mimesis, artist, absolutistic monarchy, Severans, anonymity, pessimism, cultural decline 
Название статьи. Когда и почему античное искусство стало анонимным

Сведения об авторе. Корсо Антонио - доктор, научный сотрудник. Фонд Костопулоса, Livyis 2 a, Zografou, GR 15771, Афины, Греция. antoniocorso@hotmail.com ORCID: 0000-0002-8090-4274

Аннотация. В этой статье обсуждается проблема того, почему античное искусство стало анонимным в поздней античности. Есть эстетические причины: считается, что изобразительное искусство больше не реагирует на мимесис, а на «фантазию», поэтому образы имеют трансцендентное происхождение и больше не приписываются конкретным художникам. Более того, переход Римской империи от конституционной монархии к абсолютистской подразумевает, что памятники теперь приписываются особенно императорскому покровительству, художники и архитекторы обесцениваются. Упадок классической культуры, широко распространённые пессимистические настроения и, наконец, отрыв западной части Римской империи от классического греческого наследия завершают эту картину. Однако древние художники снова станут известными с IX и X веков. Художники упоминаются и считаются важными до периода Северов. С этого времени упоминания о художниках становятся редкими и исчезают. Этот процесс обусловлен радикальным изменением эстетической теории (фантазия становится более важной, чем мимесис), превращением Римской империи в абсолютистскую монархию, упадком классического образования, наконец, установлением культуры, которая рассматривает произведения искусства как прозрения божеств, а не творения художников.

Ключевые слова: фантазия, мимесис, художник, абсолютистская монархия, Северы, анонимность, пессимизм, культурный упадок 